\title{
Efficiency of Students' Needs Assessment Application Facilitated by Text Communication Media
}

\author{
Guruh Sukma Hanggara, Nora Yuniar Setyaputri*, Restu Dwi Ariyanto \\ Department of Guidance and Counseling, Faculty of Teacher Training and Education, Universitas Nusantara PGRI Kediri, \\ K.H. Ahmad Dahlan Street No. 76, Kediri, East Java, Indonesia 64112 \\ *corresponding author, e-mail: setyaputrinora@gmail.com
}

Article received: September $13^{\text {th }} 2019$; revised: November $14^{\text {th }} 2019$; accepted: November $26^{\text {th }} 2019$

\begin{abstract}
Needs assessment is the main thing performed by school counselors as a basis for developing a guidance and counseling service program. In conducting needs assessment, problems that frequently occur are related to ratios, feasibility and practicality of instruments, as well as needs assessment procedures. One solution that can be used to overcome these problems is the use of application analysis needs of students based on text communication media. This research aims to determine the efficiency of students' needs analysis application based on text communication media on vocational high school students. The research method used was experiment with the one-group pretest-posttest design technique. The research population was 45 vocational high school counselors in Kediri city. The percentage of random sampling was $25 \%$ of the total population, so the number of subjects was 11 people. The research instrument was the Students' Needs Efficiency Assessment Questionnaire by the school counselor and interviews. The research data were analyzed in descriptively and comparative tests. Based on the analysis results, the needs assessment of text-based media communication is to improve the efficiency of students' assessment declared efficient.
\end{abstract}

Keywords: application; needs analysis; text communication; efficiency

\begin{abstract}
Abstrak: Assessment kebutuhan merupakan hal pokok yang dilakukan konselor sekolah sebagai dasar dalam menyusun program layanan bimbingan dan konseling. Dalam pelaksanaan assessment kebutuhan, kerap terjadi masalah terkait rasio, kelayakan dan kepraktisan instrumen, maupun prosedur assessment kebutuhan. Salah satu solusi yang dapat digunakan untuk mengatasi masalah tersebut adalah penggunaan aplikasi analisis kebutuhan siswa berbasis media komunikasi teks. Penelitian ini bertujuan untuk mengetahui efisiensi aplikasi analisis kebutuhan siswa berbasis media komunikasi teks pada siswa sekolah menengah kejuruan. Metode penelitian yang digunakan adalah eksperimen dengan teknik one-group pretest-posttest design. Populasi penelitian adalah konselor sekolah menengah kejuruan sekota Kediri yang berjumlah 45 orang. Persentase pengambilan sampel secara acak sebesar $25 \%$ dari total populasi, sehingga jumlah subjek sebesar 11 orang. Instrumen penelitian menggunakan Kuisioner Efisiensi Assessment Kebutuhan Siswa oleh konselor sekolah dan wawancara. Data penelitian dianalisis secara deskriptif dan uji beda. Berdasarkan hasil analisis, assessment kebutuhan berbasis media komunikasi teks untuk meningkatkan efisiensi assessment siswa dinyatakan efisien.
\end{abstract}

Kata kunci: aplikasi; analisis kebutuhan; komunikasi teks; efisiensi

\section{INTRODUCTION}

Assessment is an evaluation method to better comprehend individual characteristics, the environment, and other matters (Hays, 2014). By conducting a needs assessment first, we can develop an effective program (Cohen \& Angeles, 2006). Likewise, in the preparation of a guidance and counseling service program, school counselors need to conduct an assessment to be able to make an effective program (Gysbers \& Henderson, 2012). In the implementation of guidance and counseling, assessment of students' needs is an integral component in the development and implementation of guidance and

How to cite: Setyaputri, N. Y., Hanggara, G. S., \& Ariyanto, R, D. (2019). Efficiency of Students' Needs Assessment Application Facilitated by Text Communication Media. Jurnal Kajian Bimbingan dan Konseling, 4(4), 150-156. https://doi.org/10.17977/um001v4i42019p150 
counseling programs at schools (Thompson et al., 2003). The needs assessment can also be used by school counselors to meet the students' needs according to their developmental tasks and guide them towards optimal and mature development (Yusuf, 2009).

Needs assessment is not an easy and rapid activity to do. Facts on the ground show that students who are the responsibility of a school counselor exceed the ideal ratio (Hanggara et al., 2018). In addition, another problem in conducting the assessment is the instrument limitations (Thompson et al., 2003). The limitations are in the form of the appropriateness of the instruments owned, understanding, and knowledge related to the use of the instrument and its administration skills. In administering and analyzing instruments, constraints are frequently encountered due to time, thought, energy, and cost. This makes school counselors tend to conduct needs assessment carelessly or even missed. Some school counselors at vocational high schools in Kediri city complain about the needs assessment process. They consider that the needs assessment process is a saturating activity. Needs assessment process consuming a lot of time, thought, and energy because the number of school counselors and students is imbalanced. The imbalance is feared to make the analysis results of students' data to be inaccurate and do not reflect students' real condition, which can lead to errors in the selection of guidance and counseling service strategies.

The imbalanced ratios may also reduce the analysis accuracy conducted by school counselors. In order to minimize inconsistencies in assessment caused by the counselor's subjectivity, it needs adequate resources (Sebok \& MacMillan, 2014), and other solutions. Another solution offered is the use of technologies that can make procedures and analyzes to be consistent and objective. One of these technologies is the application assessment of students' needs facilitated by text communication media.

At the beginning of its development, applications that were tested for effectiveness were developed focusing on using Short Message Service (SMS). Based on the acceptance test results, the application is in the excellent category (Hanggara et al., 2018), the use of simple text communication media has a minor but important role by catalyzing communication lines (Jones et al., 2009). Then, in the development process, it gets many suggestions to suit the development and communication trends by using WhatsApp, Google form, and Facebook messenger. Researchers continue to revise according to various suggestions so that the value of this application is increasingly sophisticated and feasible to use. The next development process is testing the effectiveness of applications in limited groups to get further feedback. In the effectiveness test, it will be obtained various information related to the effectiveness of the application and information that is certainly useful for further improvements before it is widely used.

Based on the urgency written in the previous paragraph, the objectives of this research are: (1) determining the efficiency of assessment implementation on vocational students without using text-based needs analysis applications; (2) determining the efficiency of assessment implementation on vocational students using text-based needs analysis applications; (3) determining the level of effectiveness of textbased students' needs analysis applications in improving the efficiency of assessment implementation on vocational students.

\section{METHOD}

The research method used was experiment. The independent variable was students' needs assessment application facilitated by text communication media while the dependent variable was the efficiency of students' needs assessment implementation conducted by the school counselor. Specifically, the experimental technique used in this research was the one-group pretest-posttest design. This design was part of the pre-experimental group. There were three steps in implementing this design, namely: (1) conducting a pretest to measure the dependent variable; (2) applying treatment; and (3) provide a posttest to re-measure the dependent variable. The success of the treatment was determined by comparing the results of the pretest and posttest (Borg \& Gall, 1983; Darmadi, 2011).

One-group pretest-posttest design was used, because generally the system at schools or certain institutions does not allow any other different treatment for the research subjects, the omission of this control group is not a serious thing that can threaten internal validity (Borg \& Gall, 1983). This can be minimized by controlling extraneous variables that can interfere with internal validity, such as history, maturity, testing, instrumentation, statistical regression, differential selection, mortality, and selectionmaturation interactions (Borg \& Gall, 1983; Darmadi, 2011; Sukmadinata, 2012). 
In this research, several methods used to control extraneous variables were by arranging similar but not the same pretest and posttest instruments. The instrument was developed from the same indicator but the statements between the pretest and posttest questionnaires were made differently. This was intended to minimize the threat of extraneous validity for the instrumentation section. Then, the researcher examined that less efficiency in conducting the assessment of students' needs was a phenomenon experienced by open research subjects because researchers' subjectivity. It was important to select treatment/ intervention really needed by the research subject.

The research subject was school counselors who were incorporated into the Association of Vocational High School Counselor (MGBK). The sampling technique used was simple random sampling with a percentage of $25 \%$ of the total population. The population was 45 vocational high school counselor in Kediri city, so the number of subjects was 11 people.

The instrument used was the Efficiency Assessment Questionnaire for Students' Needs by the Counselor and interview guidelines. The questionnaire was compiled based on indicators formulated from expert opinions, namely: selecting, administering, scoring, and reporting assessment results (Hays, 2014; Watson \& Flamez, 2014; Whiston, 2012). The validation process of the 21 items questionnaire was performed through an expert test involving two competent Guidance and Counseling lecturers. Then, it was tabulated and analyzed using the specified inter-rater agreement method (Gregory, 2011). Expert tests were conducted to obtain validation of the product being developed. The validity used in this research and development was content validity. Content validity measurement was performed to measure whether the elements in the instrument were relevant to the research variables. The three criteria used in the expert test index were unfavorable/ inadequate in the range of $0.00-0.33$, quite good/ quite decent in the range of 0.34-0.66, and good/ decent in the range of 0.67-1.00. The appraisers were two competent Guidance and Counseling lecturers. Based on the test results, it was obtained expert test index by 1 . The results of this calculation were included in the first criteria in the range of values from 0.67-1.00. Thus, according to the assessment of the Guidance and Counseling lecturers, the instrument was declared as good/ worthy of acceptance/ suitable to use. This questionnaire was used to explore the efficiency of students' needs assessment data by school counselors before and after using the tested application. Qualitative data obtained from interview subjects were used to complement the research results.

In this research, calculations were performed using Paired Samples Test (parametric statistics); if the data were normal and homogeneous, if the data were abnormal and not homogeneous, then the Wilcoxon Sign Rank Test was used (non-parametric statistics). The decision-making provisions in the hypothesis test were if the significance was less than 0.05 , then the null hypothesis was rejected, whereas if the significance score was more than 0.05 , then the null hypothesis was accepted. Qualitative data would be described and it would be concluded from the description, to provide a clear picture of the aspects being assessed.

\section{RESULTS}

The results of the pretest and posttest are presented in Table 1. Based on Table 1, it is known that before the intervention, five subjects had an understanding categorized as low criteria (L), five subjects had an understanding categorized as high criteria $(\mathrm{H})$, and one subject was categorized as very high $(\mathrm{VH})$. After an intervention in the form of providing materials and practices using Text Communication Media Based Needs Analysis Application, from the data obtained, the assessment efficiency of students' needs increased. Seven subjects obtained high criteria $(\mathrm{H})$, and four subjects obtained very high criteria $(\mathrm{VH})$. Then, the prerequisite test including normality test and homogeneity test to determine the hypothesis test, was performed using parametric or nonparametric statistics.

Normality test results show a significance score of 0.504 , and it be seen that the data are normally distributed because the significance score is higher than 0.05 . Homogeneity test results show a score of 0.871 , which means homogeneous data because the significance score is greater than 0.05 . Because the data is normally distributed and homogeneous, the hypothesis test uses parametric paired sample test statistics. The calculation results using the paired sample test are presented in Table 2, which shows that the significance score of the paired samples test is 0.000 . Based on the magnitude of the score, it can be 
Table 1. Recapitulation of Pretest and Posttest Results

\begin{tabular}{cccccc}
\hline No. & Name & Pretest Score & Criteria & Posttest Score & Criteria \\
\hline 1 & LEP & 38 & L & 53 & H \\
2 & NAK & 42 & L & 48 & H \\
3 & FM & 42 & L & 47 & H \\
4 & VT & 38 & L & 50 & H \\
5 & MAR & 51 & H & 59 & VH \\
6 & JNW & 43 & H & 56 & VH \\
7 & DIW & 46 & H & 51 & H \\
8 & ENH & 54 & VH & 58 & VH \\
9 & FFA & 48 & H & 48 & H \\
10 & MRI & 39 & L & 49 & H \\
11 & BST & 49 & H & 57 & VH \\
\hline
\end{tabular}

Table 2. Paired Samples Test

\begin{tabular}{|c|c|c|c|c|c|c|c|c|c|}
\hline & & \multicolumn{5}{|c|}{ Paired Differences } & \multirow[b]{3}{*}{$\mathbf{t}$} & \multirow[b]{3}{*}{ df } & \multirow[b]{3}{*}{$\begin{array}{c}\text { Sig. } \\
\text { (2-tailed) }\end{array}$} \\
\hline & & \multirow[b]{2}{*}{ Mean } & \multirow[b]{2}{*}{$\begin{array}{c}\text { Std. } \\
\text { Deviation }\end{array}$} & \multirow[b]{2}{*}{$\begin{array}{l}\text { Std. Error } \\
\text { Mean }\end{array}$} & \multicolumn{2}{|c|}{$\begin{array}{l}95 \% \text { Confidence Interval } \\
\text { of the Difference }\end{array}$} & & & \\
\hline & & & & & Lower & Upper & & & \\
\hline Pair 1 & $\begin{array}{l}\text { Posttest - } \\
\text { Pretest }\end{array}$ & 7.818 & 4.423 & 1.334 & 4.847 & 10.790 & 5.862 & 10 & .000 \\
\hline
\end{tabular}

seen that the hypothesis is rejected and the alternative hypothesis is accepted because the significance score of 0.000 is smaller than 0.05 . Then, the use of text communication media-based needs analysis applications to improve the efficiency of students' assessment can be stated as efficient.

\section{DISCUSSION}

Research results show that text communication media can be combined with computer programs (Graham et al., 2012; Olaleye et al., 2013). In line with this research, Ms. Excel can be combined with text communication media. It is concisely performed with DAST (Display, Answer, Send and Transfer). In the display stage, the counselor displays the answer format and the problem/instrument needs to be worked on. School counselors can package assessment instruments in the form of statements or questions that must be answered by students in the form of Ms. PowerPoint, so it is more efficient (paperless).

Then, the students answer according to the specified answer format. After finishing to answer and all items are confirmed, they send it to the counselor via text communication media. The choice of text communication media types, namely: SMS, WhatsApp, Facebook Messenger, and Google Form, depends on the counselor and student agreement and the availability of the media used. Then, it ends with transferring the students' answers to this application by the counselor. It can be automatically analyzed without having to count manually. By this application, the counselors do not need to input so many students one by one data that can lead to psychological saturation in the needs assessment process.

The novelty element of the application of students' needs assessment facilitated by this text communication media is the application used by school counselors to facilitate the process of vocational students' needs assessment, especially to administer and analyze students' data. This application was developed by creating logical formulas in the Ms. Excel by the researchers. Software like Ms. Excel offers a concrete way to explore abstract concepts from mathematical calculations (Chaamwe \& Shumba, 2016). Everyone can create their own formulas by manipulating and combining built-in formulas to suit the analytical procedure and the objectives that want to be achieved.

Computerization in counseling and guidance services has grown in recent years (Sumarwiyah \& Zamroni, 2017). Therefore, this application is used to facilitate the use of computerization in guidance and counseling services. Text communication-based media assessment application has the advantage 
that the data of students' needs transferred to the application will be automatically analyzed with the output in the form of statistical presentations, charts, and profile scales related to students' needs both in terms of personal and group. Referring to the analysis results, school counselors can provide follow-up by choosing appropriate guidance and counseling service strategies.

Referring to the results of expert tests in previous research of Hanggara et al., (2018), text communication-based media assessment application is appropriate to be used as an instrument for assessing students' needs. With some improvements and developments, this application is tested for effectiveness. Based on this research results, it can be seen that the use of students needs assessment application facilitated by text communication media to improve the efficiency of students' assessment can be said to be effective. Based on interview data with the research subjects after using the application, it is obtained information that using the application can speed up the tabulation process. The results of automated needs analysis can be seen. It can also shorten the length of students' needs series assessment processes. The use of various kinds of text communication media (SMS, WhatsApp, Google Form, and Facebook Messenger) is an interesting innovation.

From the four types of text communication media, the research subjects are very interested in WhatsApp and Google Form. They are interested in WhatsApp because it is the most often used. Interest in Google Form is related to the novelty of this type of media when it is used in the needs assessment process. The weakness of this application is that if some numbers/ items that have not been selected, it is difficult to detect so it must be re-checked from the beginning. The solution offered for further product improvement is to isolate the tenth of the tabulated data in the excel analysis sheet.

The benefits of this application in improving the efficiency of needs assessment implementation can also be seen from the sincerity of the research subjects in following the instructions and practices. In conducting research, the research subjects show high enthusiasm. The research subjects' enthusiasm is one indicator that changes in the pretest and posttest scores, which are the results of the research conducted. The research subjects' enthusiasm is also one of the research results because the topic examined is important in the guidance and counseling service activities, which is about assessing students' needs that must be met by school counselors. Needs assessment is important because it determines the quality of the guidance and counseling program implementation (Anni, 2012). The guidance and counseling program will be effective if it is based on real needs and objective conditions of student development (Kurniawan, 2015). With the importance of a topic such as assessment and analysis of students' needs, it tends to be followed with enthusiasm.

The research subjects' sincerity is also due to the use of information technology that can ease the task of school counselors in conducting needs assessment. The utilization of information technology is an important factor in guidance and counseling services (Triyono \& Febriani, 2018). This is also supported by research showing that increasing the technological competency and information of school counselors can make the administration of guidance and counseling to be more time saving, especially in the analysis of assessment results (Cahyawulan et al., 2019).

Generation $\mathrm{Z}$ uses information and communication technology with high intensity (Bakti \& Safitri, 2017). Under these circumstances, educational media suitable for Generation $Z$ is technology media, including in the needs assessment activities. Information technology is used as a means to obtain, process, store, and also disseminate information in guidance and counseling services (Setiawan, 2016). By utilizing a needs assessment, regarding the application that uses technology and accommodates existing information and communication to these students, this needs analysis application becomes more efficient.

Students' needs analysis application can be used paperlessly. Besides being efficient and economical, this application also educates to be more environmentally friendly. The use of cellphones as answer sheets and power points or e-book formats as question sheets makes the implementation of needs assessment as paperless and environmentally friendly guidance and counseling service.

The assessment implementation using this application seeks to accommodate the various stages of guiding and counseling assessment implementation, as mentioned by Hays, (2014); Watson \& Flamez, (2014); and Whiston, (2012) namely: selecting administering, scoring, reporting assessment result. The clear stages and flow of the needs assessment using this application make the assessment to be more effective and scientifically responsible. 
The needs analysis application of vocational students was developed by creating a logical formula in the Ms. Excel program. This program is noted for its toughness in data analysis and processing, as well as displaying results quickly. Ms. Excel can indeed display data visually and develop results reports to demonstrate accountability in the implementation of counseling services (Brott, 2006). Therefore, the application development of Ms. Excel makes the data analysis and display to be more practical and efficient. Its ability to analyze data automatically in accordance with the combined logical formula makes the analysis of students' needs to be more effective and efficient.

\section{CONCLUSION}

Text communication media-based needs analysis application utilization to improve students' assessment efficiency can be stated as efficient. In order to simplify the process of assessing the students' needs, school counselors can utilize text communication media-based needs analysis application. Because based on the results of this research using the application, the implementation of students' needs assessment can be made more efficient.

\section{REFERENCES}

Anni, C. T. (2012). Need Assesment Model Penyusunan Program Bimbingan dan Konseling Bidang Bimbingan Belajar Berbantuan Sistem Informasi Manajemen di SMA Negeri Kota Semarang. Educational Management, $1(1)$.

Bakti, C. P., \& Safitri, N. E. (2017). Peran Bimbingan dan Konseling untuk Menghadapi Generasi Z dalam Perspektif Bimbingan dan Konseling Perkembangan. Jurnal Konseling GUSJIGANG, 3(1), 104-113.

Borg, W. R., \& Gall, M. D. (1983). Educational Research: An Introduction. In New York. Longman Publishing.

Brott, P. E. (2006). Counselor Education Accountability: Training the Effective Professional School Counselor. Professional School Counseling, 10(2), 179-188. https://doi.org/10.1177/2156759X0601000204

Cahyawulan, W., Badrujaman, A., Fitriyani, H., Mamesah, M., Wahyuni, E., \& Djunaedi, D. (2019). Peningkatan Kompetensi Teknologi dan Informasi Guru Bimbingan dan Konseling. CARADDE: Jurnal Pengabdian Kepada Masyarakat, 1(2), 195-199. https://doi.org/10.31960/caradde.v1i2.76

Chaamwe, N., \& Shumba, L. (2016). ICT Integrated Learning: Using Spreadsheets as Tools for e-Learning, A Case of Statistics in Microsoft Excel. International Journal of Information and Education Technology, 6(6), 435-440. https://doi.org/10.7763/IJIET.2016.V6.728

Cohen, E., \& Angeles, J. (2006). School-Based Prevalence Assessment of The Need for Mental Health Services: Survey Development and Pilot Study. Research on Social Work Practice, 16(2), 200-210. https://doi. org/10.1177/1049731505283379

Darmadi, H. (2011). Metode Penelitian Pendidikan. Bandung: Alfabeta.

Graham, C. M., Anchors, S., \& Doore, B. E. (2012). Student Learning Preferences and SMS Text Messaging: A Web 2.0 Large Classroom Engagement System. International Journal of Information and Communication Technology Research, 2(8), 638-645.

Gregory, R. J. (2011). Validity and Test Development. Psychological Testing; History, Principles and Applications 6th Ed. Boston: Allyn \& Bacon, 109-151.

Gysbers, N. C., \& Henderson, P. (2012). Developing \& Managing: Your School Guidance \& Counseling Program (5th ed). American Counseling Association.

Hanggara, G. S., Ariyanto, R. D., Andrianie, S., \& Ariyanto, R. D. (2018). Pengembangan Aplikasi Assessment Menggunakan Media Short Message Service. Jurnal Kajian Bimbingan dan Konseling, 3(4), 146-153. https://doi.org/10.17977/um001v3i32018p146

Hays, D. G. (2014). Assessment in Counseling: A Guide to The Use of Psychological Assessment Procedures. John Wiley \& Sons.

Jones, G., Edwards, G., \& Reid, A. (2009). How Can Mobile SMS Communication Support and Enhance A First Year Undergraduate Learning Environment? ALT-J, 17(3), 201-218.

Kurniawan, L. (2015). Pengembangan Program Layanan Bimbingan dan Konseling Komprehensif di SMA. Jurnal Psikologi Pendidikan \& Konseling, 1(1), 1-8.

Olaleye, O., Olaniyan, A., Eboda, O., \& Awolere, A. (2013). SMS-Based Event Notification System. Journal of Information Engineering and Applications, 3(10), 55-62. 
Sebok, S. S., \& MacMillan, P. D. (2014). Assessment of A Master of Education Counselling Application Selection Process using Rasch Analysis and Generalizability Theory. Canadian Journal of Counselling and Psychotherapy, 48(2), 108-126.

Setiawan, M. A. (2016). Peranan Teknologi Informasi dalam Bimbingan dan Konseling. Bitnet Jurnal Pendidikan Teknologi Informasi, 1(1), 46-49.

Sukmadinata, N. S. (2012). Metode Penelitian Pendidikan. PT Remaja Rosdakarya.

Sumarwiyah, S., \& Zamroni, E. (2017). Pemanfaatan Tekonologi Informasi (TI) dalam Layanan Bimbingan dan Konseling Sebagai Representasi Berkembangnya Budaya Profesional Konselor dalam Melayani Siswa. Jurnal Bimbingan dan Konseling Ar-Rahman, 2(1), 1-14.

Thompson, D. W., Loesch, L. C., \& Seraphine, A. E. (2003). Development of An Instrument to Assess The Counseling Needs of Elementary School Students. Professional School Counseling, 7(1), 35-39.

Triyono, T., \& Febriani, R. D. (2018). Pentingnya Pemanfaatan Teknologi Informasi oleh Guru Bimbingan dan Konseling. JUANG: Jurnal Wahana Konseling, 1(2), 74-83.

Watson, J. C., \& Flamez, B. (2014). Counseling Assessment and Evaluation. SAGE.

Whiston, S. C. (2012). Principles and Applications of Assessment in Counseling. Cengage Learning.

Yusuf, S. (2009). Program Bimbingan dan Konseling di Sekolah. 